\title{
PENGARUH PROMOSI JABATAN, PENGENDALIAN DAN MOTIVASI KERJA TERHADAP KEPUASAN KERJA DINAS PENGELOLAAN SUMBER DAYA AIR KABUPATEN PESISIR SELATAN
}

\author{
R.S. Afriyanti, Febsri Susanti \\ Sekolah Tinggi Ilmu Ekonomi KBP \\ rinirs74@gmail.com \\ febsrisusanti@akbpstie.ac.id
}

\begin{abstract}
In a government organization, employees become an important component of the smoothness and effectiveness of agencies. The organization needs to respond in every event that changes outside and within the agency in order to improve performance while increasing the level of employee job satisfaction. If the Dinas Pengelolaan Sumber Daya Air Kabupaten Pesisir Selatan pays attention to the promotion of work, control and work motivation more wisely, it can encourage an increase in employee job satisfaction itself. The purpose of this study are to determine the effect of promotion, control and motivation on employee job satisfaction at the the Dinas Pengelolaan Sumber Daya Air Kabupaten Pesisir Selatan. The method used is multiple linear regression analysis. The sample used were 49 peoples from 95 populationsand using simple random sampling technique to determine the sample of the study. Data processing using SPSS Version 18 Program. The results of the influence of position promotion, control and work motivation against job satisfaction were $53.3 \%$, and $46.7 \%$ were again influenced by other variables not examined in this study. It can be concluded that promotion, control and work motivation simultaneously have a positive and significant impact on employee job satisfaction.
\end{abstract}

Keywords: Promotion, Control, Motivation, Job Satisfaction

\section{PENDAHULUAN}

Dalam suatu organisasi Pemerintahan, pegawai merupakan faktor yang sangat penting bagi kelancaran dan keefektifan Instansi. Manusia memiliki akal, perasaan, keinginan, kemampuan, keterampilan, pengetahuan, dorongan, daya dan karya. Di sisi lain instansi mengharapkan pegawainya dapat bekerja dengan baik, memiliki produktivitas yang tinggi serta mampu menjabarkan visi dan misi yang telah ditetapkan untuk mencapai tujuan perusahaan. Sehingga untuk dapat mengelola dan memanfaatkan sumber daya manusia diperlukan pengelolaan dan pengendalian yang baik.

Permasalahan kepuasan kerja pegawai menjadi perhatian yang besar bagi setiap instansi. Menurut Robbins (2006: 101) "Secara umum kepuasan kerja didefenisikan sebagai sikap umum seorang individu terhadap pekerjaannya". 
Sikap tersebut berasal dari persepsi individu tentang pekerjaannya. Lebih lanjut Robbins (2006:103) menyatakan bahwa faktor-faktor yang mempengaruhi kepuasan kerja yaitu suasana pekerjaan, pengendalian, gaji, hubungan mitra kerja (interpersonal) dan promosi jabatan Selain itu menurut Blum dan Naylor dalam Wijono (2010:101) bahwa kepuasan kerja merupakan hasil dari berbagai sikap yang ditunjukkan oleh pegawai, sikap ini berkaitan dengan pemberian gaji, pengawasan, situasi, peluang untuk maju (Promosi), penghargaan dan penilaian pekerjaan yang adil dari atasan.

Pada dasarnya promosi jabatan merupakan salah satu bagian dari program penempatan yang dilaksanakan oleh Dinas atau Intansi terkait. Penempatan pegawai dilakukan dengan membuat penyesuaian terhadap kebutuhan instansi yang berhubungan dengan perencanaan untuk memperoleh orang yang tepat pada posisi yang tepat. Apabila Dinas salah dalam melakukan promosi jabatan tidak sesuai dengan skill dan kemampuan serta dengan ketentuan promosi yang berlaku maka pegawai tidak akan puas dengan pekerjaan baru yang mereka peroleh dari promosi jabatan tersebut, karena promosi jabatan ini erat kaitannya dengan kepuasan kerja pegawai.

Menurut Robbins (2007:10) pengendalian merupakan fungsi managemen dimana pengendalian merupakan suatu proses memantau, mengawasi kinerja aktual pegawai dibandingkan dengan sasaran yang telah ditentukan sebelumnya, seandainya terdapat penyimpangan ini merupakan tugas manager untuk mengembalikan kinerja pada jalurnya. Selain itu pengendalian dalam organisasi sangatlah penting karena tidak ada pegawai yang sempurna.

Dinas Pengelolaan Sumber Daya Air (PSDA) Kabupaten Pesisir Selatan merupakan salah satu OPD yang membidangi pekerjaan umum pada bagian pengairan. Dinas ini memiliki jumlah Pegawai Negeri Sipil sebanyak 95 orang. Berdasarkan pengamatan dan observasi yang penulis lakukan di Dinas Pengelolaan Sumber Daya Air (PSDA) Kabupaten Pesisir, diduga tingkat kepuasan kerja karyawan masih rendah. Dalam hal kemangkiran pegawai pihak Dinas telah menerapkan sistem aturan disiplin bagi pegawai yang melakukan pelanggaran dengan memberikan teguran, hukuman, phunising dan sanksi kepada pegawai yang kurang disiplin karena ini berdampak kepada kepuasan kerja pegawai.

Fenomena yang ada pada Dinas Pengelolaan Sumber Daya Air (PSDA) Kabupaten Pesisir mengenai promosi jabatan pegawai yang penulis dapat dari melakukan observasi di lapangan terlihat dimana pimpinan Dinas kurang memperhatikan posisi jabatan yang kosong pada setiap Bidang. seperti adanya pegawai yang sudah pensiun atau dimutasikan ke Dinas yang lain dan ada yang mengikuti pelatihan dan training tapi belum juga ada pergantian posisi yang ditinggalkan oleh pegawai tersebut. Selain itu ada juga pegawai yang sudah layak untuk dipromosikan ke tingkat yang tinggi dari semulanya dimana pegawai tersebut telah memenuhi ketentuan dan standar yang telah ditetapkan oleh Dinas untuk dipromosikan tetapi pihak Dinas belum juga melakukan promosi jabatan kepada pegawai tersebut, ini akan berdampak kepada kepuasan kerja pegawai dalam aktifitas sehari-harinya. 
Pengendalian yang dilakukan Dinas Pengelolaan Sumber Daya Air Kabupaten Pesisir Selatan dalam memantau, mengawasi kinerja pegawai dan organisasi untuk menentukan apakah tujuan yang telah ditetapkan Dinas sudah tercapai secara maksimal. Pengendalian berperan dalam menentukan tingkat kepuasan kerja, jika pengendalian terlalu tegas dan ketat kepada pegawai, maka pegawai akan terbebani dan kepuasan kerjanya akan menurun. Pengendalian tidak hanya memantau kehadiran pegawai tetapi juga melaksanakan peraturan, melatih pegawai serta memberikan saran-saran, dan informasi tentang kualitas pekerjaan yang harus dikerjakan oleh pegawai guna meningkatkan kepuasan kerja pegawai tersebut.

Motivasi kerja sangatlah penting dalam melakukan pengendalian dan promosi jabatan terhadap pegawai dan organisasi dalam upaya mencapai tujuan organisasi. Pentingnya motivasi karena motivasi adalah hal yang menyebabkan, menyalurkan, dan mendukung perilaku manusia supaya mau bekerja giat dan antusias mencapai hasil yang optimal. Motivasi semakin penting karena pimpinan membagikan pekerjaan pada bawahannya utnuk dikerjakan dengan baik dan terintegrasi kepada tujuan yang diinginkan.

Berdasarkan uraian diatas, penulis menduga tingkat kepuasan kerja pegawai ini dipicu oleh adanya promosi jabatan dan pengendalian serta motivasi kerja terhadap pekerjaan yang dilakukan pegawai. Oleh karena itu, apabila pihak Dinas Pengelolaan Sumber Daya Air Kabupaten Pesisir Selatan memperhatikan promosi jabatan, pengendalian dan motivasi kerja secara lebih bijak, maka hal ini dapat mendorong peningkatan kepuasan kerja pegawai itu sendiri.

Bertitik tolak dari latar belakang dan fenomena di atas, maka penulis tertarik untuk melakukan penelitian yang berjudul "Pengaruh Promosi Jabatan, Pengendalian dan Motivasi kerja Terhadap Kepuasan Kerja pegawai Dinas Pengelolaan Sumber Daya Air Kabupaten Pesisir Selatan”.

\section{KAJIAN TEORI \\ Kepuasan Kerja}

Pada dasarnya kepuasan kerja merupakan hal yang bersifat individual, karena setiap individu memiliki tingkat kepuasan yang berbeda-beda sesuai dengan nilai yang berlaku dalam diri setiap individu. Semakin banyak aspek dalam pekerjaan yang sesuai dengan individu, maka semakin tinggi tingkat kepuasan yang dirasakan.Menurut Robbins (2006: 101) "Secara umum kepuasan kerja didefinisikan sebagai sikap umum seorang individu terhadap pekerjaannya". Sikap tersebut berasal dari persepsi individu tentang pekerjaannya.

\section{Faktor - faktor yang mempengaruhi Kepuasan Kerja}

Menurut Mullin dalam Wijono (2010:106) menjelaskan faktor-faktor yang dapat mempengaruhi kepuasan kerja meliputi:

1) Faktor Pribadi di antaranya kepribadian, pendidikan, intelegensi dan kemampuan, usia dan orietasi kerja.

2) Faktor sosial diantaranya hubungan dengan rekan kerja, kelompok kerja, dan norma-norma, kesempatan untuk berinteraksi dan organisasi formal. 
3) Faktor budaya diantaranya sikap-sikap yang mendasari, kepercayaan dan nilai-nilai.

4) Faktor organisasi diantaranya sifat dan ukuran pengendalian / pengawasan dan gaya kepemimpinan, sistem managemen dan kondisi kerja.

5) Faktor lingkungan diantara ekonomi, sosial, teknik dan pengaruh pemerintah.

Faktor-faktor kepuasan kerja menurut Hasibuan (2003: 203) adalah sebagai berikut:

1) Balas jasa yang adil dan layak

2) Penempatan yang tepat dan sesuai dengan keahlian

3) Berat ringannya pekerjaan

4) Suasana dan lingkungan pekerjaan

5) Peralatan yang menunjang pelaksanaan pekerjaan

6) Sikap pimpinan dalam kepemimpinannya

7) Sifat pekerjaan monoton atau tidak

\section{Promosi Jabatan}

Pengertian promosi jabatan menurut Hasibuan (2003:108) merupakan perpindahan yang memperbesar authority dan responbility pegawai ke jabatan yang lebih tinggi di dalam suatu organisasi sehingga hak, status, dan penghasilan mereka akan semakin besar. Hal ini berarti seseorang memperoleh promosi jabatan akan memliki wewenang dan tanggung jawab yang lebih besar karena memperoleh jabatan yang lebih tinggi. Selain itu efek yang ditimbulkan adalah hak, status, dan penghasilan yang berupa upah / gaji dan tunjangan lainnya, akan

\section{Indikator Promosi Jabatan}

Menurut Winardi dalam Tohardi (2002:383) pengetahuan menggenai siapa yang harus dipromosikan dicapai melalui catatan-catatan yang mencakup yaitu prestasi kerja pegawai yang bersangkutan,kemampuan pekerja, dan masa dinasnya.Sedangkan Hasibuan (2003:107) mengatakan bahwa Promosi jabatan berarti ada kepercayaan dan pengakuan mengenai kemampuan serta kecakapan pegawai bersangkutan untuk menduduki suatu jabatan yang lebih tinggi,dengan demikian promosi akan memberikan status sosial, wewenang (authority), tanggung jawab (responsibility), kedudukan yang lebih tinggi serta penghasilannya juga meningkat dari semulanya.

\section{Pengendalian}

Pengendalian (controlling) merupakan suatu fungsi managemen selain fungsi planning, organizing, actuating dan juga terdapat dalam fungsi managemen sumber daya manusia, pengendalian merupakan usaha sistematis managemen untuk mencapai tujuan, aktifitas yang di awasi terus menerus untuk memastikan bahwa hasilnya berada pada batas yang di inginkan. Menurut Robbins (2007:10) pengendalian merupakan fungsi managemen dimana pengendalian atau pengawasan merupakan suatu proses memantau, mengawasi kinerja aktual pegawai dibandingkan dengan sasaran yang telah ditentukan sebelumnya, seandainya terdapat penyimpangan ini merupakan tugas manager untuk mengembalikan kinerja pada jalurnya. 


\section{Ciri - ciri Indikator Pengendalian}

Menurut Siagian (2007:137) yang menjadi dasar dan indikator pengendalian adalah:

1. Standar hasil yang direncanakan untuk dicapai

2. Observasi secara keseluruhan

3. Evaluasi kinerja pegawai

4. Bimbingan dan arahan

\section{Motivasi Kerja}

\section{Pengertian Motivasi Kerja}

Motivasi berasal dari kata motif yang sering diistilahkan dengan dorongan atau tenaga. Motivasi menurut Winardi (2007:1) berasal dari bahasa latin, yakni movere yang berarti "menggerakkan" (to move). Selanjutnya Winardi (2007:2) mengungkapkan motivasi adalah hasil dari sejumlah proses yang bersifat internal atau eksternal bagi seorang individu, yang menyebabkan timbulnya sikap entusiasme dan persistensi dalam hal melaksanakan kegiatan-kegiatan tertentu.

\section{Indikator Motivasi}

Mengacu pada pendapat Robert (1992:110) dapat diambil kesimpulan indikator motivasi kerja dalam penelitian ini sebagai berikut:

1) Mengambil inisiatif

2) Mempunyai kemauan yang keras untuk bekerja

3) Berorientasi pada sasaran atau hasil kerja

4) Suka tantangan dan disiplin

5) Memberi andil yang lebih dari yang diharapkan

\section{Kerangka Konseptual}

Keterkaitan antara variable bebas dan variable terikat dapat digambarkan skemanya sebagai berikut :

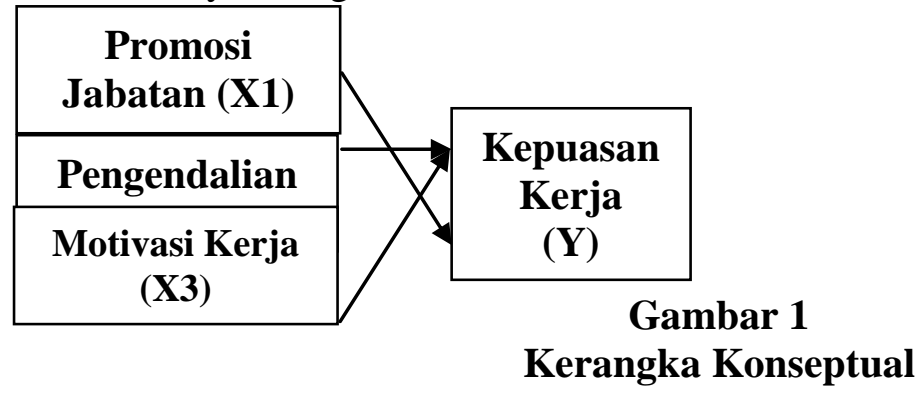

\section{METODE PENELITIAN}

\section{Rancangan Penelitian}

Jenis penelitian ini adalah penelitian bersifat kuantitatif. Penelitian ini akan dilakukan pada Dinas Pengelolaan Sumber Daya Air Kabupaten Pesisir Selatan Populasi dalam penelitian ini adalah seluruh pegawai Dinas Pengelolaan Sumber Daya Air Kabupaten Pesisir Selatan pada Tahun 2015 yang berjumlah 95 orang

Sampel menurut Sugiyono (2013) adalah bagian dari jumlah dan karakteristik yang dimiliki populasi tersebut. Oleh karena itu, sampel yang diambil dari populasi harus betul-betul mewakili. Berdasarkan rumus Slovin maka, dihasilkan jumlah sampel penelitian yang digunakan adalah 49 orang pegawai Dinas PSDA Kab. Pesisir Selatan. Teknik Sampling yang peneliti pakai 
adalah simple random sampling yang merupakan teknik penentuan sampel yang dilakukan secara acak tanpa memperhatikan perbedaan yang ada dalam populasi (Sugiyono, 2013).

\section{Definisi Operasional dan Pengukuran Variabel}

Untuk menyamakan persepsi antara penulis dan pembaca, maka penulis akan mengemukakan definisi operasional masing-masing definisi operasional masing-masing variabel yang digunakan, yaitu:

a. Kepuasan Kerja (Y)

Pengertian kepuasan kerja yang dimaksudkan dalam penelitian ini adalah perasaan atas pekerjaan menyokong atau tidak menyokong dari pegawai yang berhubungan dengan pekerjaan maupun dengan kondisi kerjanya dan kepuasan kerja menggambarkan sikap seseorang atas perasaan senang atau tidak senang, puas atau tidak puas dalam bekerja.

b. Promosi Jabatan $\left(\mathrm{X}_{1}\right)$

Promosi Jabatan dalam penelitian ini merupakan proses perpindahan yang pegawai dari suatu jabatan ke jabatan yang lain yang mempunyai tangung jawab yang lebih tinggi dalam suatu organisasi sehinga kewajiban, hak dan status yang lebih tinggi.Adapun indikator dalam penelitan ini adalah (1) Tanggung jawab yang lebih besar, (2) Kedudukan yang lebih tinggi, (3) Prestasi kerja, (4) wewenang/authority, (5) Penghasilan yang diterima.

c. Pengendalian $\left(\mathrm{X}_{2}\right)$

Pengendalian yang dimaksud dalam penelitian ini adalah suatu proses untuk memonitor kerja pegawai apakah sesuai dengan rencana yang telah ditentukan sebelumnya untuk melakukan feedback atau evaluasi bagi pegawai dalam menjalankan tugasnya.

d. Motivasi kerja $\left(\mathrm{X}_{3}\right)$

Motivasi kerja dalam penelitian ini adalah dorongan dalam diri seseorang agar mereka mau bekerja dengan upaya yang tinggi demi tercapainya tujuan organisasi. Indikator yang digunakan dalam variabel ini adalah:

Alat ukur dari semua variabel ini adalah menggunakan skala likert yaitu Selalu (SL), Sering (SR), Kadang-kadang (KD), Jarang (JR), Tidak pernah (TP). Skor yang digunakan memakai pertanyaan positif dengan cara penilaian 5,4,3,2,1.

\section{HASIL PENELITIAN DAN PEMBAHASAN \\ Deskripsi Responden Penelitian}

Karakteristik responden penelitian yang merupakan pegawai pada Dinas PSDA

Kabupaten Pesisir Selatan adalah sebagai berikut :

a. Jenis Kelamin

Pengelompokkan responden penelitian berdasarkan jenis kelamin terdiri dari 2 kelompok seperti yang dipaparkan pada Tabel 1 
Tabel 1

Distribusi Responden Berdasarkan Jenis Kelamin

\begin{tabular}{|c|c|c|c|}
\hline No & Jenis Kelamin & Frekuensi & Persentase (\%) \\
\hline 1 & Pria & 26 & 53,1 \\
\hline 2 & Wanita & 23 & 46,9 \\
\hline \multicolumn{2}{|c|}{ Total } & 49 & 100 \\
\hline
\end{tabular}

Sumber : Hasil pengolahan data tahun 2018

Dari Tabel 4.1 diketahui sebagian besar responden penelitian adalah pria $(53,1 \%)$ dan sisanya wanita $(46,9 \%)$.

b. Usia

Pengelompokkan responden penelitian berdasarkan usia terdiri dari 3 kelompok seperti yang dipaparkan pada Tabel 2.

Tabel 2

Distribusi Responden Berdasarkan Usia

\begin{tabular}{|c|c|c|c|}
\hline No & Usia & Frekuensi & Persentase (\%) \\
\hline 1 & $<30$ Tahun & 5 & 10,2 \\
\hline 2 & $31-40$ Tahun & 32 & 65,3 \\
\hline 3 & $41-50$ Tahun & 12 & 24,5 \\
\hline \multicolumn{2}{|c|}{ Total } & 49 & 100 \\
\hline
\end{tabular}

Sumber : Hasil pengolahan data tahun 2018

Dari Tabel 4.2 diketahui sebagian besar responden penelitian adalah berusia 31 tahun sampai dengan 40 tahun $(65,3 \%)$. Sisanya berusia kurang dari 30 tahun $(10,2 \%)$ dan 41 tahun sampai 50 tahun $(24,5 \%)$.

c. Lama Bekerja

Pengelompokkan responden penelitian berdasarkan lama bekerja terdiri dari 5 kelompok seperti yang dipaparkan pada Tabel 3.

Tabel 3

Distribusi Responden Berdasarkan Lama Bekerja

\begin{tabular}{|c|c|c|c|}
\hline No & Masa Kerja & Frekuensi & Persentase $(\%)$ \\
\hline 1 & $<5$ Tahun & 8 & 16,3 \\
\hline 2 & 6 - 10 Tahun & 9 & 18,4 \\
\hline 3 & 11-15 Tahun & 17 & 34,7 \\
\hline 4 & 16 - 20 Tahun & 7 & 14,3 \\
\hline 5 & $>20$ Tahun & 8 & 16,3 \\
\hline 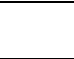 & Total & 49 & 100 \\
\hline
\end{tabular}

Sumber : Hasil pengolahan data tahun 2018

Dari Tabel 4.3 diketahui sebagian besar responden penelitian lama adalah bekerja 11-15 tahun (34,7\%). Sisanya lama bekerja kurang dari 5 tahun $(16,3 \%)$, lama bekerja 6-10 tahun $(18,4 \%)$, lama bekerja $16-20(14,3 \%)$ tahun dan lama bekerja lebih dari 20 tahun (16,3\%).

d. Tingkat Pendidikan

Pengelompokkan responden penelitian berdasarkan pendidikan terakhir terdiri dari 4 kelompok seperti yang dipaparkan pada Tabel 4. 
Tabel 4 Distribusi Responden

Berdasarkan Pendidikan Terakhir

\begin{tabular}{|c|c|c|c|}
\hline No & Pendidikan & Frekuensi & Persentase (\%) \\
\hline 1 & SMU & 5 & 10,2 \\
\hline 2 & D3 & 8 & 16,3 \\
\hline 3 & S1 & 29 & 59,2 \\
\hline 4 & S2 & 7 & 14,3 \\
\hline \multicolumn{2}{|c|}{ Total } & 49 & 100 \\
\hline
\end{tabular}

Sumber : Hasil pengolahan data tahun 2018

Dari Tabel 4.4 diketahui sebagian besar responden penelitian berpendidikan terakhir S1 (59,2\%). Sisanya berpendidikan terakhir SMU (10,2\%), berpendidikan terakhir D3 (16,3\%) dan berpendidikan terakhir S2 (14,3\%).

\section{Pengujian Instrumen}

\section{Uji Validitas dan Reabilitas}

Hasil uji validitas dan realibilitas untuk pernyataan promosi Jabatan, pengendalian, motivasi kerja dan kepuasan kerja pegawai pada Dinas Pengelolaan Sumber Daya Air Kabupaten Pesisir Selatan adalah sebagai berikut Uji Validitas

Pernyataan promosi Jabatan, pengendalian, motivasi kerja dan kepuasan kerja pegawai pada Dinas Pengelolaan Sumber Daya Air Kabupaten Pesisir Selatan dilakukan uji validitas sebagai berikut :

\section{a. Promosi Jabatan}

Hasil uji validitas pernyataan promosi jabatan yang terdiri dari 5 butir dikategorikan valid karena setiap butir pernyataan menghasilkan nilai $r_{\text {hitung }}$ (pada kolom Corrected Item-Total Correlation)> 0,300. hasil uji validitas ini berarti 5 butir pernyataan promosi jabatan dapat dilanjutkan sebagai data penelitian untuk dianalisa.

\section{b. Pengendalian}

Hasil uji validitas pernyataan pengendalian yang terdiri dari 4 butir pernyataan dikategorikan valid karena setiap butir pernyataan menghasilkan nilai $r_{\text {hitung }}$ (pada kolom Corrected Item-Total Correlation)> 0,300. hasil uji validitas ini berarti 4 butir pernyataan pengendalian dapat dilanjutkan sebagai data penelitian untuk dianalisa.

\section{c. Motivasi Kerja}

Hasil uji validitas pernyataan motivasi kerja yang terdiri dari 5 butir pernyataan dikategorikan valid karena setiap butir pernyataan menghasilkan nilai $r_{\text {hitung }}$ (pada kolom Corrected Item-Total Correlation)> 0,300. hasil uji validitas ini berarti 5 butir pernyataan motivasi kerja dapat dilanjutkan sebagai data penelitian untuk dianalisa

\section{d. Kepuasan Kerja}

Hasil uji validitas pernyataan kepuasan kerja yang terdiri dari 5 butir pernyataan dikategorikan valid karena setiap butir pernyataan menghasilkan nilai $r_{\text {hitung }}$ (pada kolom Corrected Item-Total Correlation)> 0,300. hasil uji validitas ini berarti 5 butir pernyataan kepuasan kerja dapat dilanjutkan sebagai data penelitian untuk dianalisa 


\section{Uji Reabilitas}

Setelah melakukan uji validitas kemudian dilanjutkan dengan uji reabilitas. Hasil pengolahan reabilitas untuk variabel promosi jabatan, pengendalian, motivasi kerja dan kepuasan kerja pegawai pada Dinas Pengelolaan Sumber Daya Air Kabupaten Pesisir Selatan sebelum mendiskualifikasi persyaratan yang tidak valid. Hasilnya dapat diambil kesimpulan bahwa dari uji reabilitas sebelum mendiskualifikasi pernyataan yang tidak valid dihasilkan nilai Cronbach's Alphauntuk variabel promosi jabatan, pengendalian, motivasi kerja dan kepuasan kerja adalah reliabel karena nilai Cronbach's Alpha yang dihasilkan lebih besar dari 0,600 sehingga variabel promosi jabatan, pengendalian, motivasi kerja dan kepuasan kerjayang termasuk kategori valid dapat dipakai sebagai alat ukur dalam penelitian.

\section{Analisis Data Penelitian}

\section{Uji Asumsi Klasik}

Adapun yang dilakukan dalam uji asumsi klasik ini terdiri dari uji normalitas, uji multikolineritas dan uji heteroskesdastisitas.

\section{Analisis Regresi Linier Berganda}

Hasil pengujian persamaan regresi linier berganda untuk pengaruh promosi jabatan, pengendalian, motivasi kerja dan kepuasan kerja pegawai pada Dinas Pengelolaan Sumber Daya Air Kabupaten Pesisir Selatan, maka bentuk persamaan regresi linear berganda untuk pengaruhpromosi jabatan, pengendalian, motivasi kerja dan kepuasan kerja adalah sebagai berikut :

$\mathrm{Y}=3,674+0,303 \mathrm{X}_{1}+0,364 \mathrm{X}_{2}+0,293 \mathrm{X}_{3}$

\section{Analisis Koefisien Korelasi dan Determinasi}

Hasil uji koefisien korelasi dan determinasi pengaruh promosi jabatan, pengendalian, motivasi kerja dan kepuasan kerja pegawai pada Dinas Pengelolaan Sumber Daya Air Kabupaten Pesisir Selatan dapat dilihat nilai koefisien korelasi ganda sebesar 0,730, maka tingkat hubungan variabel bebas terhadap variabel terikat termasuk kategori tinggi (berada pada interval : 0,6 s/d 0,8). Selain itu juga diperoleh koefisien determinasi sebesar 0,533, maka kontribusi atau besarnya pengaruh semua variable bebas (promosi jabatan, pengendalian, dan motivasi kerja) terhadap variable terikat (kepuasan kerja) pegawai pada Dinas Pengelolaan Sumber Daya Air Kabupaten Pesisir Selatan sebesar 53,3\%, dan 46,7\% lagi dipengaruhi oleh variabel lain yang tidak diteliti pada penelitian ini.

\section{Uji t}

Uji hipotesi dilakukan dalam bentuk uji t. Hasil uji t untuk pengaruh promosi jabatan, pengendalian, dan motivasi kerja secara satu per satu terhadap kepuasan kerja pegawai pada Dinas Pengelolaan Sumber Daya Air Kabupaten Pesisir Selatan dapat dikemukakan hasil uji t, yaitu :

1. Dari output perhitungan SPSS Versi 18 di atas pengaruh $X_{1}$ terhadap $Y$ didapat $\mathrm{t}$ hitung $>\mathrm{t}$ tabel $(3,064>2,021)$ nilai Sig. $(\mathrm{p})<$ Sig. $\alpha(0,004<0,05)$ maka Ho ditolak dan Ha diterima, berarti terdapat pengaruh yang signifikan dan positif antara variable Promosi Jabatan $\left(\mathrm{X}_{1}\right)$ terhadap Variabel Kepuasan $\operatorname{Kerja~(Y)~}$ 
2. Dari output perhitungan SPSS versi 18 di atas pengaruh $X_{2}$ terhadap $Y$ didapat $\mathrm{t}$ hitung $>\mathrm{t}$ tabel $(2,928>2,021)$ nilai Sig. $(\mathrm{p})<$ Sig. $\alpha(0,005<0,05)$ maka Ho ditolak dan Ha diterima, berarti terdapat pengaruh yang signifikan dan positif antara variable Pengendalian $\left(\mathrm{X}_{2}\right)$ terhadap Variabel Kepuasan $\operatorname{Kerja~(Y)~}$

3. Dari output spss di atas pengaruh $\mathrm{X}_{3}$ terhadap $\mathrm{Y}$ didapat $\mathrm{t}$ hitung $>\mathrm{t}$ tabel $(2,673>2,021)$ nilai Sig. $(\mathrm{p})<$ Sig. $\alpha(0,010<0,05)$ maka Ho ditolak dan Ha diterima, berarti terdapat pengaruh yang signifikan dan positif antara variable Motivasi Kerja $\left(\mathrm{X}_{3}\right)$ terhadap Variabel Kepuasan Kerja (Y)

\section{Uji F}

Uji hipotesis dilakukan dalam bentuk uji $\mathrm{F}$ untuk pengaruh promosi jabatan, pengendalian, dan motivasi kerja secara bersamaan terhadap kepuasan kerja pegawai pada Dinas Pengelolaan Sumber Daya Air Kabupaten Pesisir Selatan dikemukakan nilai $\mathrm{F}$ hitung $=17,124$ dan nilai Sig. sebesar 0,000 , dimana nilai $\mathrm{F}$ hitung $>$ F tabel $(17,124>2,82)$ dan nilai Sig. $(p)<$ Sig. $\alpha(0,000<0,05)$, maka $\mathrm{H}_{\mathrm{o}}$ ditolak dan $\mathrm{H}_{\mathrm{a}}$ Diterima, berarti dapat disimpulkan "terdapat pengaruh yang signifikan dan positif antara Variable $\mathrm{X}_{1}, \mathrm{X}_{2}$ dan $\mathrm{X}_{3}$ Secara Bersama-sama terhadap Variabel Y"

\section{PEMBAHASAN}

Penelitian yang dilakukan mengenai pengaruh pengaruh promosi jabatan, pengendalian, dan motivasi kerja secara bersamaan terhadap kepuasan kerja pegawai pada Dinas Pengelolaan Sumber Daya Air Kabupaten Pesisir Selatan menggunakan sampel 49 orang yang merupakan pegawai lingkup Dinas Pengelolaan Sumber Daya Air Kabupaten Pesisir Selatan.

Dari hasil uji t yang dilakukan nilai $t$ hitung promosi jabatan $(3,064)$, pengendalian $(2,928)$, motivasi kerja $(2,673)>\mathrm{t}$ tabel $(2,021)$ dan nilai signifikansi promosi jabatan, pengendalian dan motivasi kerja secara satu persatu berpengaruh signifikan terhadap kepuasan kerja pegawai pada Dinas Pengelolaan Sumber Daya Air Kabupaten Pesisir Selatan. Demikian pula dengan hasil uji F yang dilakukan menghasilkan nilai $\mathrm{F}$ hitung $17,124>\mathrm{F}$ tabel 2,82 dan nilai signifikansi yang dihasilkan 0,000 <level of significant 0,05 . Hasil uji $\mathrm{F}$ berarti pengaruh promosi jabatan, pengendalian, dan motivasi kerja secara bersama-sama berpengaruh siginifikan terhadap kepuasan kerja pegawai pada Dinas Pengelolaan Sumber Daya Air Kabupaten Pesisir Selatan. Besarnya pengaruh promosi jabatan, pengendalian, dan motivasi kerja secara bersamaan terhadap kepuasan kerja Dinas Pengelolaan Sumber Daya Air Kabupaten Pesisir Selatan adalah sebesar 53,3\%, dan $46,7 \%$ lagi dipengaruhi oleh variabel lain yang tidak diteliti pada penelitian ini.

\section{SIMPULAN}

Dari hasil penelitian ini dapat disimpulkan sebagai berikut :

1. Promosi jabatan $\left(\mathrm{X}_{1}\right)$ berpengaruh positif dan signifikan terhadap Kepuasan Kerja (Y) pegawai di Dinas Pengelolaan Sumber Daya Air Kabupaten Pesisir Selatan dengan dilihat dari output perhitungan SPSS versi 18 dimana 
pengaruh $\mathrm{X}_{1}$ terhadap $\mathrm{Y}$ didapat $\mathrm{t}$ hitung $>\mathrm{t}$ tabel $(3,064>2,021)$ nilai Sig. (p) < Sig. $\alpha(0,004<0,05)$ maka Ho ditolak dan Ha diterima.

2. Pengendalian $\left(\mathrm{X}_{2}\right)$ berpengaruh positif dan signifikan terhadap Kepuasan Kerja (Y) pegawai di Dinas Pengelolaan Sumber Daya Air Kabupaten Pesisir Selatan dengan dilihat dari output perhitungan SPSS versi 18 dimana pengaruh $\mathrm{X}_{2}$ terhadap $\mathrm{Y}$ didapat didapat $\mathrm{t}$ hitung $>\mathrm{t}$ tabel $(2,928>2,021)$ nilai Sig. (p) $<$ Sig. $\alpha(0,005<0,05)$ maka Ho ditolak dan Ha diterima.

3. Motivasi Kerja $\left(\mathrm{X}_{3}\right)$ berpengaruh positif dan signifikan terhadap Kepuasan Kerja (Y) pegawai di Dinas Pengelolaan Sumber Daya Air Kabupaten Pesisir Selatan dengan dilihat dari output perhitungan SPSS Versi 18 dimana pengaruh $\mathrm{X}_{3}$ thdap $\mathrm{Y}$ didapat $\mathrm{t}$ hitung $>\mathrm{t}$ tabel $(2,673>2,021)$ nilai Sig. (p) $<$ Sig. $\alpha(0,010<0,05)$ maka Ho ditolak dan Ha diterima.

4. Promosi jabatan, pengendalian dan motivasi kerja secara bersamaan berpengaruh positif dan signifikan terhadap Kepuasan Kerja pegawai di Dinas Pengelolaan Sumber Daya Air Kabupaten Pesisir Selatandengan dilihat dari output pengolahan SPSS Versi 18 dimana nilai $\mathrm{F}$ hitung $=17,124$ dan nilai Sig. sebesar 0,000 , dimana nilai $F$ hitung $>F$ tabel $(17,124>2,82)$ dan nilai Sig. $(p)<$ Sig. $\alpha(0,000<0,05)$, maka $\mathrm{H}_{\mathrm{o}}$ ditolak dan $\mathrm{H}_{\mathrm{a}}$ Diterima.

5. Penelitian yang dilakukan menggunakan sampel 49 orang yang merupakan pegawai lingkup Dinas Pengelolaan Sumber Daya Air Kabupaten Pesisir Selatan.

\section{UCAPAN TERIMA KASIH}

Penulis mengucapakan terima kasih kepada:

1. Bapak Febryandhie Ananda, SE, M.Si selaku ketua STIE "KBP” Padang.

2. Ibu Lidhya Marta, SE, MM selaku wakil ketua "STIE KBP" Padang.

3. Ibu Febsri Susanti, SEI, MM selaku ketua program studi manajemen dan sekaligus pembimbing skripsi yang sangat rendah hati dan membimbing kami dengan penuh kesabaran.

4. Bapak Irdha Yusra, SE, M.Sc selaku dosen pembimbing akademik dan dosen pembimbing proposal yang sangat rendah hati dan membimbing kami dengan penuh kesabaran dari awal proposal.

5. Semua dosen, dan staff yang telah berbagi ilmu dan waktunya sehingga membantu penulis menjadi orang yang memiliki ilmu dan dapat menyelesaikan tugas akhir ini.

6. Bapak Ir. H. Doni Gusrizal, MM selaku Kepala Dinas Pengelolaan Sumber Daya Air Kabupaten Pesisir Selatan yang telah memberi izin penulis untuk melakukan penelitian serta dalam memperoleh data.

\section{DAFTAR PUSTAKA}

Aldi, Y., \& Susanti, F. (2019). Pengaruh Stress Kerja Dan Motivasi Kerja Terhadap Prestasi Kerja Karyawan Pada PT. Frisian Flag Indonesia Wilayah Padang. https://doi.org/10.31227/osf.io/et4rn

Bhuono, Agung Nugroho, 2005. Strategi Jitu Memilih Metode Statistik Penelitian Dengan SPSS. Yogyakarta.Andi 
Daft, Richard L.2003.Manajemen. Edisi Kelima. Jakarta: Erlangga.

Dale, Timpe A. 2000. Seri Manajemen Sumber Daya Manusia, Kepemimpinan, Gramedia, Jakarta

Hasibuan, Malayu S.P. 2003, Manajemen Sumber Daya Manusia, Edisi Revisi,Bumi Aksara, Jakarta

Luthans, F. 2006. Perilaku Organisasi. Edisi Kesepuluh.Diterjemahkan oleh: Yuwono,Vivin Andika. Yogyakarta: Andi.

Maringan,Masry S. 2004.Dasar-Dasar Administrasi dan Manajemen.Jakarta: Ghalia Indonesia.

Mayliza, R. (2019). Pengaruh Kompensasi Finansial, Lingkungan Kerja Dan Motivasi Kerja Terhadap Kinerja Pegawai Pada Kantor PDAM Kota Payakumbuh. https://doi.org/10.17605/OSF.IO/DZXAF

Mayliza, R. (2019). Pengaruh Gaya Kepemimpinan Dan Disiplin Kerja Terhadap Kinerja Karyawan Dengan Motivasi Kerja Sebagai Variabel Intervening Pada PT. Semen Padang. https://doi.org/10.17605/OSF.IO/FYPQ9.

Mayliza, R. (2019). Pengaruh Stres Kerja Dan Kesempatan Promosi Terhadap Turnover Intention Pada CV. Anisa Fadly Kabupaten Padang Pariaman. https://doi.org/10.17605/OSF.IO/PCDV2

Nawawi, Hadari. 2000. Manajemen Sumber Daya Manusia Untuk Bisnis yang Kompetitif, Yogyakarta. Gajah Mada University Press.

Panggabean, Mutiara S. (2002). Manejemen Sumber Daya Manusia. Bogor: Ghali Indonesia.

Ramlan, Ruvendi. 2005.Imbalan dan Gaya Kepemimpinan Pengaruhnya TerhadapKepuasan Kerja Karyawan, Balai Besar Industri Hasil Pertanian Bogor.Jurnal Ilmiah Binaniaga Vol 01 No 1 Tahun 2005,Pdf

Ridho, M., \& Susanti, F. (2019). Pengaruh Stres Kerja Dan Motivasi Kerja Terhadap Kepuasan Kerja Pada Karyawan Bank Mandiri Syariah Cabang Padang. https://doi.org/10.31227/osf.io/pa2cg

Rivai, Veitzhal. 2005.Manajemen Sumber Daya Manusia Untuk Perusahaan : dari Teori ke Praktik.Jakarta. PT.Raja Grafindo Persada

Robbins,P.Stephen.2006. Perilaku Organisasi.Edisi Sepuluh. Diterjemahkan oleh: Drs. Benyamin Molan. Erlangga, Jakarta. 
Sugiyono,2013, MetodelogiPenelitianKuantitatif,KualitatifDan R\&D. Bandung. Alfabeta

Thomas W Zimmerer, Norman M Scarborough.2008. Kewirausahaan dan ManajemenUsaha Kecil, Jakarta. Salemba Empat

Tohardi,Akhmad,2002.Manajemen Sumber Daya Manusia Untuk Perusahaan. Jakarta: PT. Raja Gravindo Persada

Wexley Kenneth N and Yuki Gary A. 1992. Perilaku Organisasi dan Psikologi Personalia. terjemahan Muh. Shobaruddin, Jakarta: Rineka Cipta.

Wijono, Sutarto. 2010. Psikologi Industri dan Organisasi. Kencana : Jakarta

Yudistira, D. S., \& Susanti, F. (2019). Pengaruh Motivasi Kerja Dan Budaya Kerja Terhadap Kinerja Karyawan Dinas Pemberdayaan Masyarakat Dan Desa, Pengendalian Penduduk Dan Keluarga Berencana Kabupaten Pesisir Selatan. https://doi.org/10.31227/osf.io/jk54m 